\title{
Characterization of Major Ion Chemistry and Hydro-Geochemical Processes in Mt. Elgon Trans-Boundary Aquifer and Their Impacts on Public Health
}

\author{
Japhet Rugendo Kanoti* Daniel Olago Norbert Opiyo Christopher Nyamai \\ Edwin Dindi Zachary Kuria \\ Department of Geology, University of Nairobi, P.O. Box 30197 - 00100 Nairobi, Kenya
}

\begin{abstract}
There is a gradual paradox shift from the utilization of surface water to groundwater in both urban and rural Kenya. This is because surface water is both diminishing in quantity due to climate variability and deteriorating in quality due to high levels of anthropogenic contamination. In the quest to attain the Sustainable Development Goal number 6 that aim at ensuring access to safe water by all by 2030, the Government of Kenya is encouraging the development of groundwater resources whose potential is enormous though it has not been quantified. The Inter-governmental Authority on Development (IGAD) supported this research on the shared Mt. Elgon transboundary aquifer between Kenya and Uganda aimed at understanding its dynamics. Mt. Elgon is a Tertiary age mountain that straddles the Kenya-Uganda border and has a trans-boundary aquifer. This study investigated the groundwater chemistry and its implication on water management and human health. Physico-chemical parameters of water that included electrical conductivity, $\mathrm{pH}$, and temperature were measured in the field and the major cations and anions were measured at the Central Laboratories of the State Department for Water. Geological mapping and identification of sanitary risks were undertaken during the field work. The study revealed that the concentration of cations and anions in the groundwater varied spatially and temporally. Abundance of these ions were in the order $\mathrm{Ca}^{2+}>\mathrm{Na}^{+}>\mathrm{Mg}^{2+}>\mathrm{K}^{+}$for most samples and $\mathrm{HCO}_{3}^{-}>\mathrm{Cl}^{-}>$ $\mathrm{SO}_{4}{ }^{2-}>\mathrm{NO}_{3}{ }^{-}$. Interpretation of hydro-chemical data suggests that calcium carbonate dissolution, halite dissolution, $\mathrm{Ca} / \mathrm{Na}$ ion exchange and $\mathrm{Mg} / \mathrm{Na}$ ion exchange are the major processes that control the ground-water chemistry. Chemical results indicate further that the groundwater is suitable for domestic use but is threatened by both anthropogenic and geological factors. Extensive use of fertilizer and the destruction of the catchment area coupled with low permeability and rock-water interactions in the metamorphic rock terrains are the main threats to groundwater quality in the region. A few water points had water with some ionic composition exceeding WHO and the local KEBS maximum limits for drinking water. Such water pose a risk to human health.
\end{abstract}

Keywords: Transboundary aquifer, groundwater chemistry, Human health, Carbonate dissolution, Mt. Elgo, Kenya

DOI: $10.7176 /$ JEES/9-4-06

Publication date: April $30^{\text {th }} 2019$

\section{Introduction}

Access to clean and safe water remains a problem for many countries in Sub-Saharan Africa. There is limited renewable water supply in Kenya (World Health Organization \& UNICEF, 2017). According to the joint monitoring report of 2017 by WHO and UNICEF, the proportion in rural population in Kenya with piped water increased from $18 \%$ to $22 \%$ between 2000 and 2015 but reduced in urban areas from $85 \%$ to $61 \%$ during the same period. In the same report, the proportion of population using non-piped water increased from $26 \%$ to $38 \%$ and $7 \%$ to $26 \%$ in rural and urban areas respectively between the same periods. In many rural areas, groundwater is the only feasible way of providing safe and reliable water supplies for sustaining livelihoods, food security and safeguarding the environment (MacDonald, et. al, 2011). However, since the resource is invisible, it is vulnerable to many natural and man-induced threats (Gleeson et al., 2012). These threats include overabstraction, climate change vulnerability and pollution (Taweesin, Seeboonruang, \& Saraphirom, 2018). According to a UN report, by 2025 two third of the world will be under the threat of water deficit (UN-Water, 2015). In Kenya, these threats are becoming a reality and surface water is no longer the preferred water source (Abdi \& Osman, 2012; Luedeling et al., 2015; Mailu, 1997; Oiro, et al., 2018; Wang et al., 2014). In both rural and urban areas, groundwater is being tapped for water supply (Ayalew et al., 2014; JICA, 2012; Owuor \& Foeken, 2009). The Mt Elgon aquifer provides water for domestic use to the communities surrounding the mountain in both Kenya and Uganda and it is also a strategic resource to the pastoralists in arid Karamoja and West Pokot regions in Uganda and Kenya, respectively (Chelelgo \& Mwaura, 2011).

There is a disparity in the allocation of water resources between the lowlands e.g. West Pokot and the highlands e.g. Kitale where highlands have large population concentrations, intense economic activities and abundant water whereas lowlands are sparsely populated and experiences water deficits. The need for equitable utilization of the region water resources, first for humans and livestock, then across sectors including 
environmental flows, offers an opportunity to address some of these inequalities through stakeholders' participation and integrated planning, development and management.

The Mt. Elgon aquifer has not been studied comprehensively in the past and it is therefore ill-understood. The existing information is from single drilled borehole measurements and from wells that have been dug for water supply. Water accessibility and availability is diminishing particularly in the lower pastoral and agro-pastoral zones both for domestic and livestock consumption. While it is generally recognized that there is abundant groundwater in the Mount Elgon volcanic formation, and much less so in the associated and older metamorphic rocks, there is no estimate made of the amount - many of the water points have been developed by diverse NGOs, and related groundwater information has not been collated and assessed on a regional scale, as well as its vulnerability to climate change. The understanding of the water dynamics is vital to the economic functioning of the extensive surrounding area including the arid West Pokot/Karamoja regions.

\section{Characteristics of the Mount Elgon area}

Mount Elgon is an extinct volcano that rises to 4,321 $\mathrm{m}$ above sea level. The mountain range lies astride the Kenya -Uganda border and run approximately in a north eastern - south western direction (figure1). The climate in the region ranges from equatorial climate at high elevations to arid climate in the lowlands (IPCC, 2000). Part of the study area falls within the northern semi-arid region with mean annual rainfall below $875 \mathrm{~mm}$. The mountainous region has a mean annual rainfall of about $1800 \mathrm{~mm}$ (Musau, et al.,2015). The lowland slopes of the mountain are characterized by erratic rainfall. Therefore, drought often occurs with catastrophic effects on both human and livestock.

The mountain is a recharge zone for groundwater. It is also an important water tower contributing to the waters of the Turkwel River, Lake Turkana, Lake Victoria and of the Nile River via Lake Kyoga (Lapworth, et al., 2017; Lubovich, 2009; Todd et al., 2011). The area is endowed with rich, fertile soils. Maize is the main cash crop and is grown currently between May and April. Five years ago, the maize was grown between February and March, but this has changed gradually to April-May, presumably due to climate change.

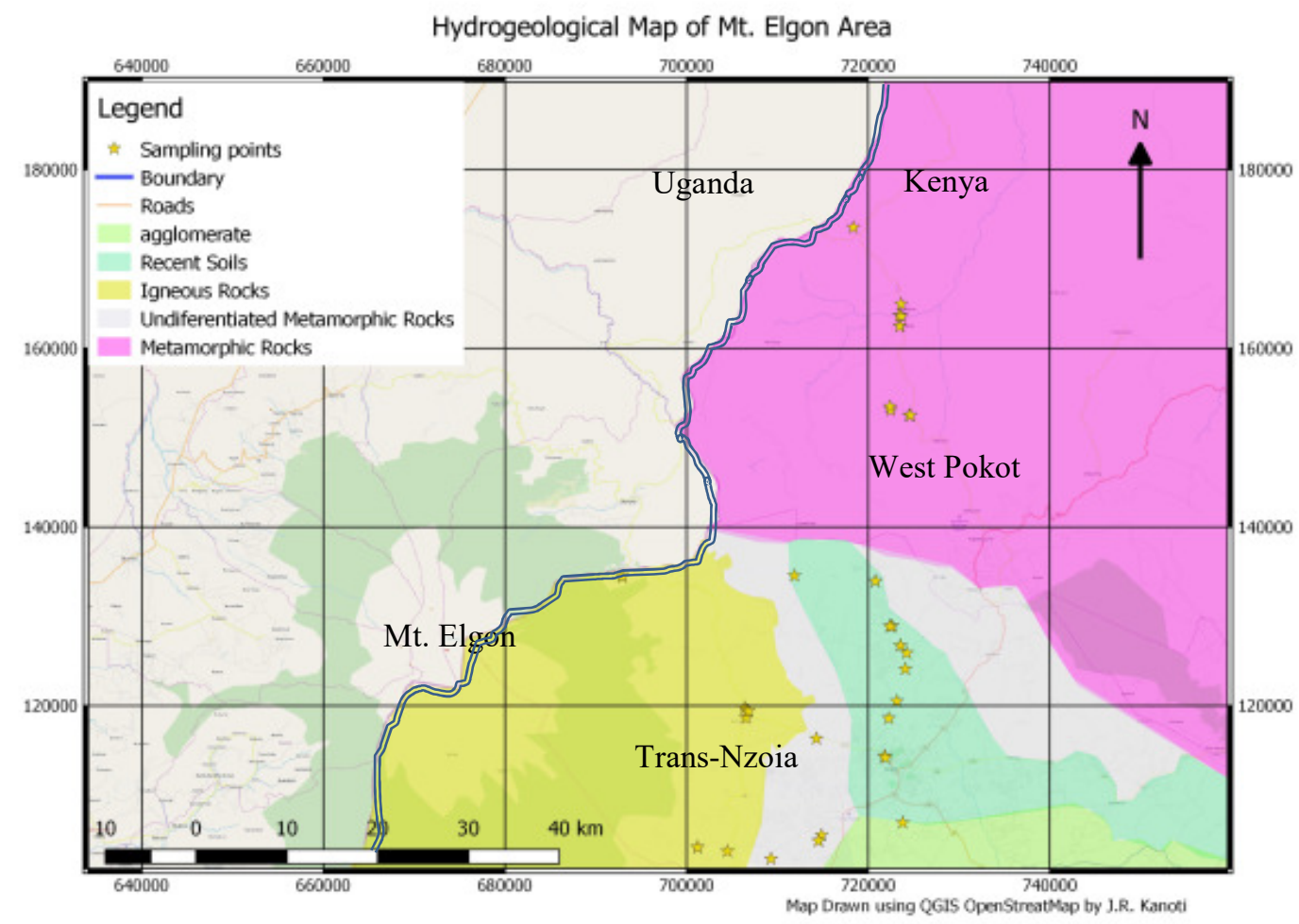

Figure 1. Hydrogeological Map of the Mt. Elgon. The sampling points are shown in the map.

The aquifer system of Mt Elgon comprises various geological formations that include volcanic agglomerates, weathered and fractured basaltic lava flows and deep volcanic ash (Figure 1). In the upper Mt. Elgon regions, the dominant geological formation is the weathered Tertiary volcanic agglomerate tuffs and fractured basalts. This formation supports good inter-granular and fracture-flow aquifers with yields from 5 to over $20 \mathrm{~m}^{3} / \mathrm{h}$. The aquifer system within the metamorphic rocks is controlled by fractures, regolith and alluvial river beds and yield little water, between $1.5-6 \mathrm{~m}^{3} / \mathrm{hr}$. 


\subsection{Methodological approach}

Field mapping of wells, boreholes and springs was undertaken between January and June 2016 and an inventory of the 23 sampling sites was established. This database included information on the global positioning system (GPS) location, water depth, elevation and depth to water table. During the same period, hydrogeological field work was undertaken to ground truth the existing geological map for the area. Secondary data such as well logs, groundwater completion reports, existing well logs and water quality was sought during the fieldwork.

A total of 23 water samples were collected during the fieldwork. Sampling points were selected after a thorough inventory of water points in the areas. Sterilized plastic bottles with double seals were used to collect the water samples. In situ measurements of electrical conductivity, temperature and $\mathrm{pH}$ were done using a portable Hanna meter. Two water samples were collected in every sampling point. Two drops of concentrated annular grade nitric acid were added to the sample for major anions analysis. Laboratory analysis was carried out using standard methods for water analyses (APHA 1989). Blanks were used to check the accuracy of the chemical analysis and the correctness of the results were verified by calculating the charge balance error.

\subsection{Results of the study}

4.1 physical chemical properties of groundwater

The descriptive statistics of the physical chemical properties of groundwater in Kisumu are shown in the table1 below and in figure 2 .

Table 1. In situ physical chemical properties of selected borehole water in Mt. Elgon area measured using a portable Hanna kit

\begin{tabular}{lllll} 
& & $\mathrm{pH}$ & $\mathrm{EC}(\mu \mathrm{s} / \mathrm{cm})$ & Temperature \\
\hline $\mathrm{N}$ & Valid & 23 & 23 & 23 \\
\cline { 2 - 5 } & Missing & 0 & 0 & 0 \\
\hline Median & & 7.0800 & 320.00 & 23.100 \\
\hline Mode & & 6.90 & 150 & 23.0 \\
\hline Minimum & & 6.09 & 60 & 13.8 \\
\hline Maximum & & 11.54 & 2510 & 28.2 \\
\hline Percentiles & 25 & 6.7000 & 150.00 & 22.800 \\
& 50 & 7.0800 & 320.00 & 23.100 \\
& 75 & 7.8200 & 750.00 & 24.900 \\
\hline
\end{tabular}

Table 1 shows the summary of physical chemical characteristics of water samples analyzed using a portable kit. From the statistics in the above table, groundwater is portable and generally safe for human consumption. However, a few shallow wells and boreholes had elevated values of conductivity. The histograms in figure 2 below shows the variability of the three parameters, namely $\mathrm{pH}$, electrical conductivity and Temperature respectively. 

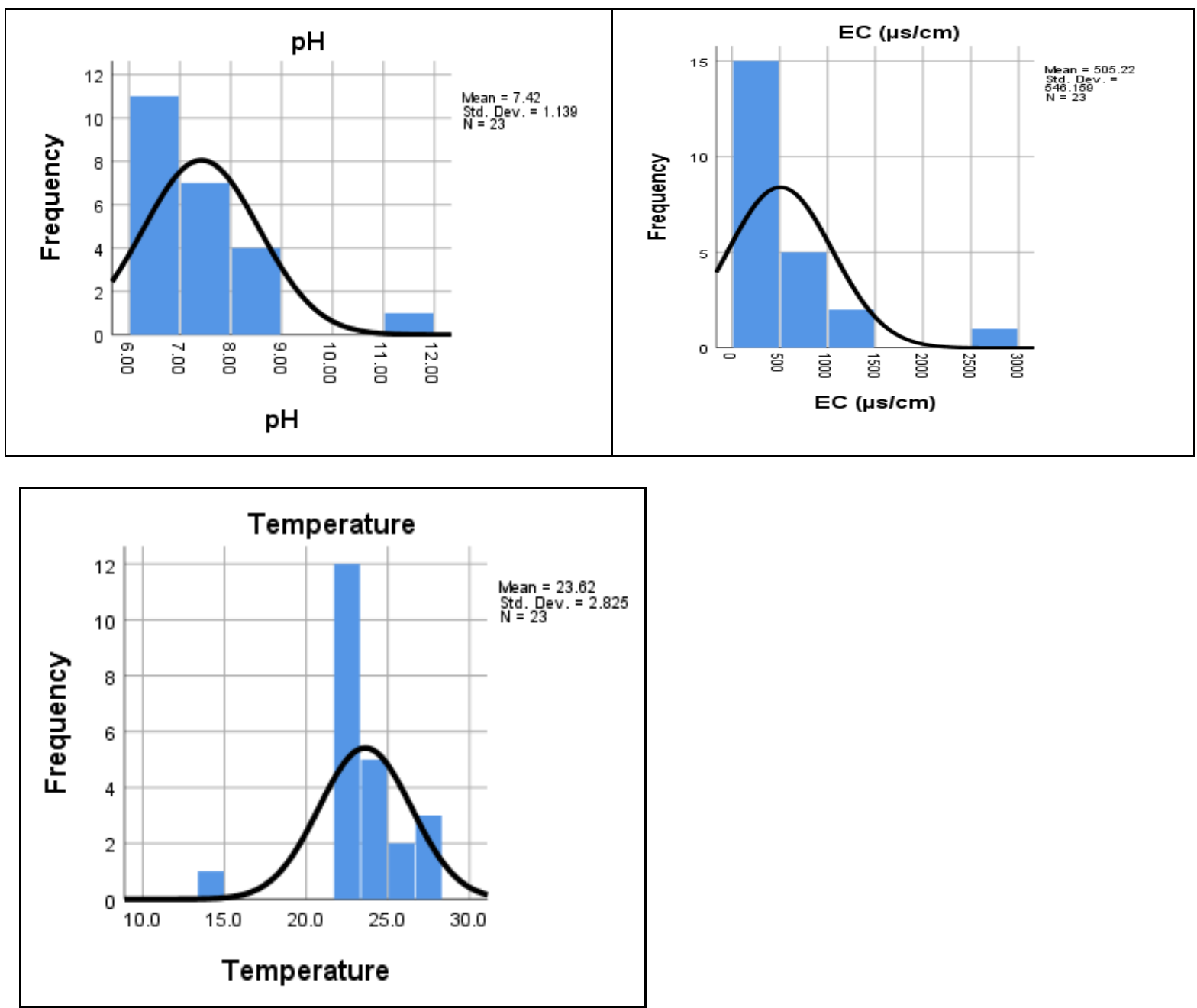

Figure 2. Histograms of $\mathrm{pH}, \mathrm{Ec}$ and temperature depicting the skewness of the physical chemical data in the study area

Figure 2 shows the distribution of temperature, $\mathrm{pH}$ and Ec (electrical conductivity) of water samples from boreholes, shallow wells and springs.

Boreholes are numerous in the area and the majority are community water points serving a radius of about 1 $\mathrm{km}$. Most institution (hospitals and schools) in the area have boreholes. Water conductivity in West Pokot is relatively high $(750-1030 \mu \mathrm{S} / \mathrm{cm})$ compared to water from the Trans-Nzoia $(120$ and $320 \mu \mathrm{S} / \mathrm{cm})$. The only anomalous values in Trans-Nzoia are from boreholes in Saboti area (over $1000 \mu \mathrm{S} / \mathrm{cm}$ ). The high values can be attributed to groundwater-rock interaction. The table below shows the physical properties of borehole water sampled during the field work. The data shows that groundwater in the study area is suitable for domestic use.

Shallow wells are widespread in the area and are alternative sources of clean portable water in Trans-Nzoia. However, in West Pokot, they are very scarce. Physical chemical analysis shows that the water is generally good for domestic use. The temperature ranges is almost the same in all the shallow wells at $23.0^{\circ} \mathrm{C}$, the $\mathrm{pH}$ is within the permissible WHO range. Electrical conductivity is however very variable and in one well it was $2510 \mu \mathrm{S} / \mathrm{cm}$. Most shallow well, however, run dry during extreme dry seasons. Shallow wells are vulnerable to pollution due to shallow depths and lack of well-head protection. Most wells were dug in close proximity to pit latrines and therefore prone to bacteriological contamination.

The spring water observed were very clear and tasteless and the chemical analysis confirms the water is good for domestic purpose. The springs are permanent and provide reliable water to the neighbouring communities. Most springs have flows that fill a 20 litre jerrycan in less than 10 minutes. Agglomerate tuff and pyroclastics outcrops in the area are porous and permeable and are sites for very productive natural springs. The springs mostly originate at the contact between the metamorphic and volcanic rocks.

4.2 Hydro-geochemical properties of groundwater

The descriptive statistics of ions in the groundwater are shown in table 4 
Table 2. Mean, median, minimum and maximum concentrations of ions, turbidity, EC and TDS for the

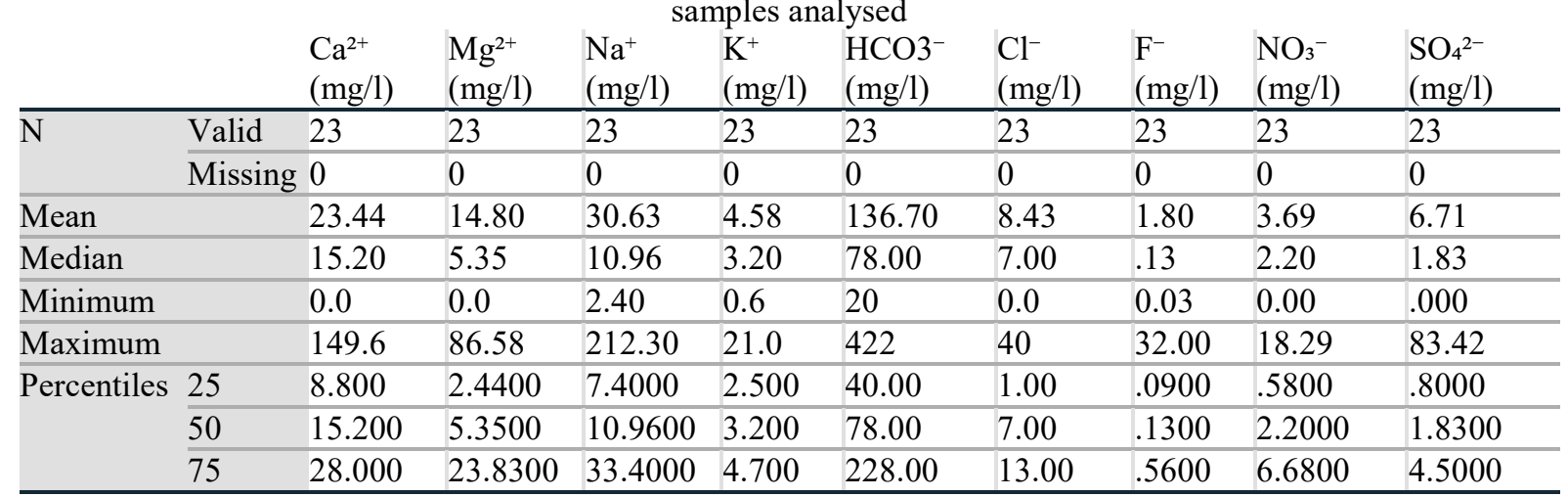

The sulphate values of $83.42 \mathrm{mg} / \mathrm{l}$ for groundwater in one well was beyond the WHO recommended value of $10 \mathrm{mg} / \mathrm{l}$ (table 2). Similarly, the values for water from three other water points were high $(8 \mathrm{mg} / \mathrm{l})$ though below WHO values. It is recommended that further studies be conducted to determine the source of these high sulfate values. Saboti sub-district Hospital borehole has water with high fluoride values of $32 \mathrm{mg} / \mathrm{l}$ that is beyond the recommended WHO value of $1.5 \mathrm{mg} / \mathrm{l}$. The concentrations of $\mathrm{Ca}^{2+}, \mathrm{Cl}^{-}, \mathrm{Mg}^{2+}, \mathrm{Na}^{+}$and $\mathrm{SO}^{2-}$ ions generally increase with the increasing total mineralization.

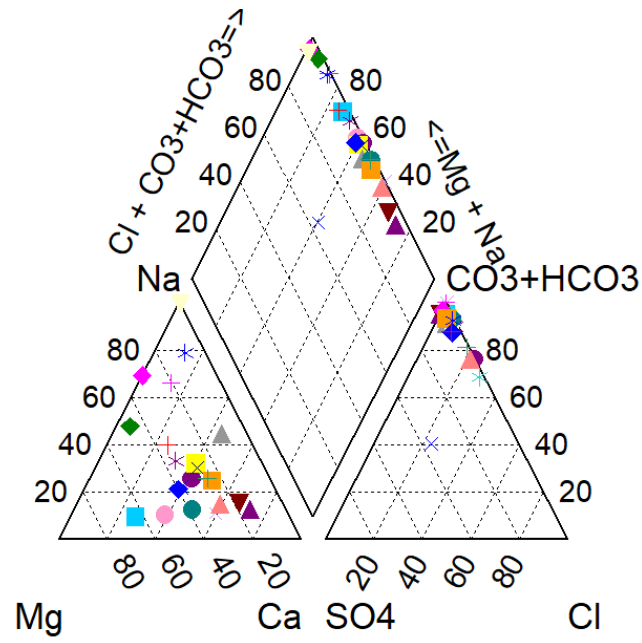

Figure 3. Piper plot of groundwater

Figure 3 is a piper plot showing the dominant ions and their relationship in the study area. The abundance of carbonate rocks and the erosion rates in the study area suggest that the dissolution of carbonate minerals may potentially add significant amounts of $\mathrm{Ca}^{2+}$ and $\mathrm{Mg}^{2+}$ to groundwater of the Mt Elgon aquifer in the metamorphic rock terrain. This is also supported by the ternary plot in figure 4 below.

4.3 Chemical classification of groundwater in Mt. Elgon

The figure below displays the ternary plots for major cations and anions of water samples from the study area. 


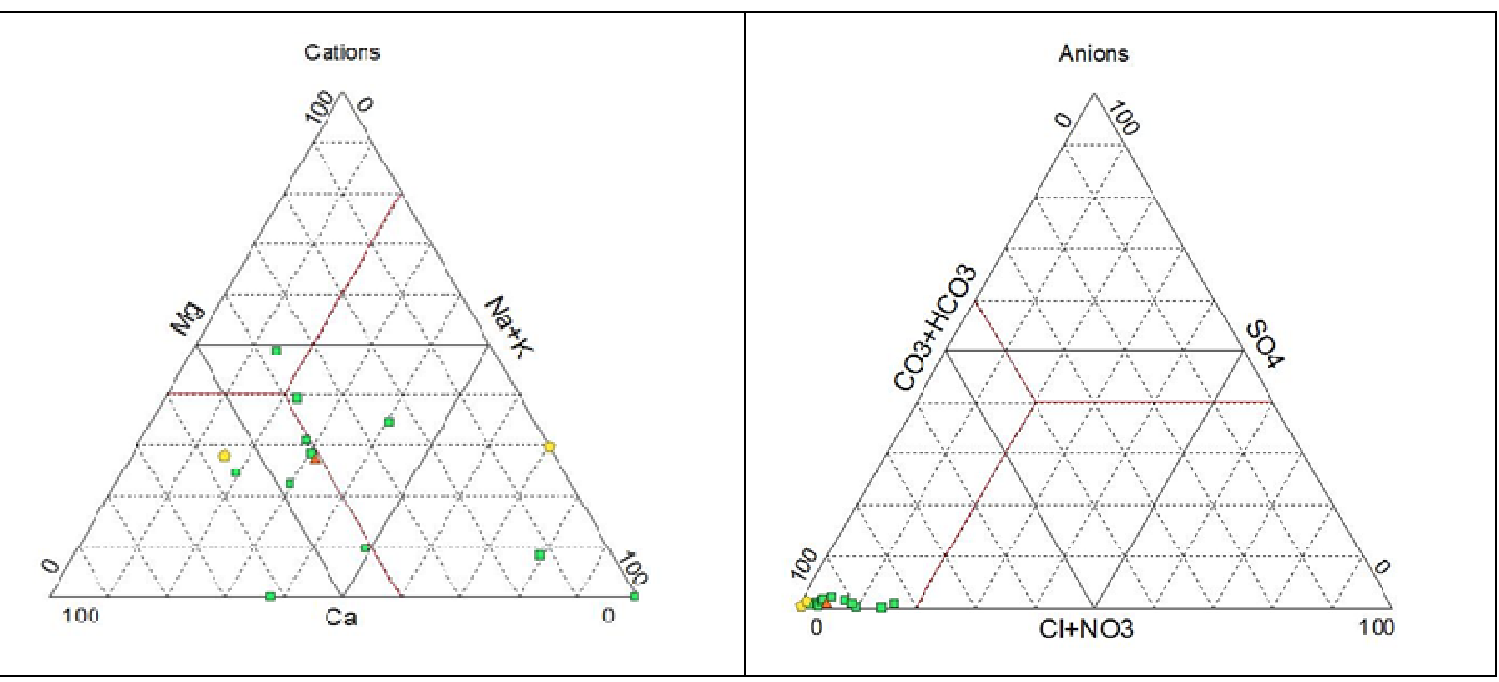

Figure 4. Plot of major ions concentration in the Mt. Elgon water

The plot shows that the water in the region is carbonate/bicarbonate rich indicating strong interaction with aquifer rock. The plot shows that the dominant water type is the $\mathrm{Ca}-\mathrm{Mg}-\mathrm{HCO} 3$. Other types are Na-HCO3 and $\mathrm{Mg}-\mathrm{Na}-\mathrm{CO} 3$

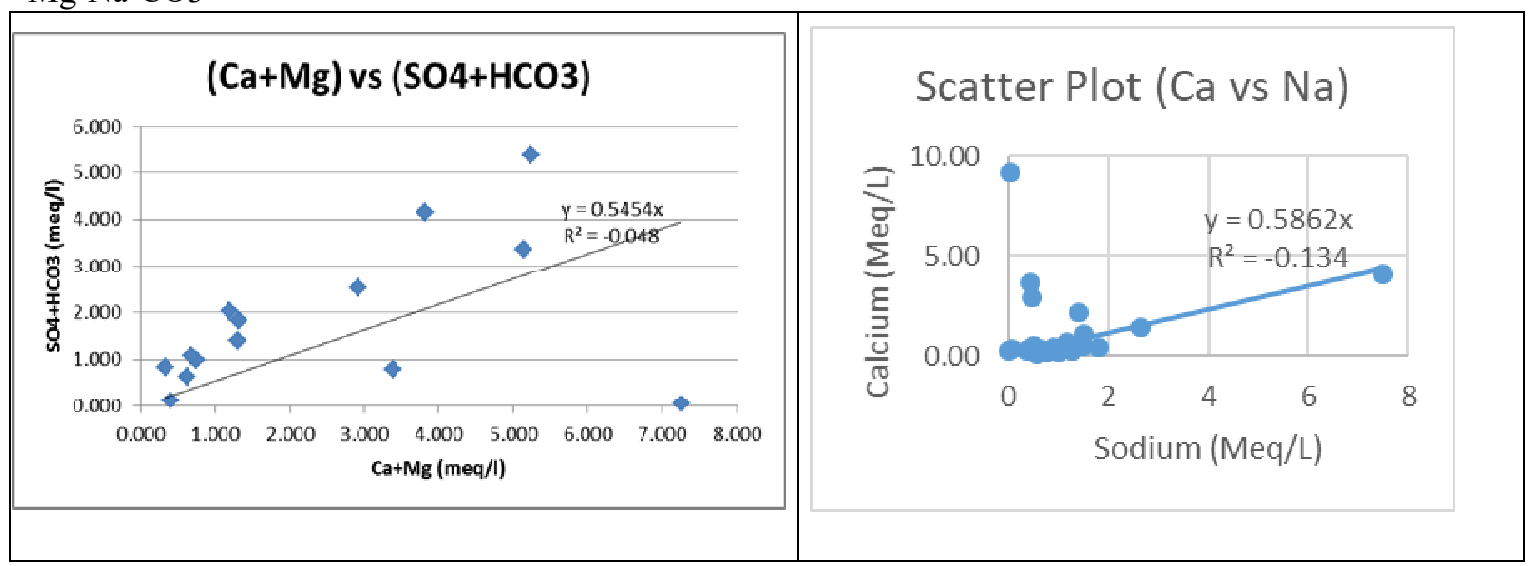

Figure 5. Scatter Diagram showing carbonate dissolution and silicate weathering equilibrium line for Mt. Elgon water samples and the $\mathrm{Ca}$ and $\mathrm{Na}$ relationship.

The concentration of ions in groundwater depend on hydrogeochemical processes taking place within the aquifer as groundwater moves toward equilibrium in ion concentration. The concentrations of ions can be used to identify geochemical processes (figure 5). Datta and Tyagi (1996) concluded that in the scatter diagram of $(\mathrm{Ca}+\mathrm{Mg})$ vs $(\mathrm{HCO} 3+\mathrm{SO} 4)$ that ionic concentrations falling above the trend-line result from carbonate weathering while those falling below the line are due to silicate weathering (Datta \& Tyagi, 1996). Majority of samples analyzed in the Mt. Elgon area falls above the line indicating that carbonate weathering is the main source for calcium.

The scatter plots shows increased concentration of $\mathrm{Ca}$ compared to $\mathrm{Na}$ for majority of samples analyzed, an indication of cation exchange. The abundance of $\mathrm{Ca}, \mathrm{Na}$ and $\mathrm{Mg}$ is associated with clay minerals like illite within the aquifer.

\subsection{Discussion}

Groundwater resources in the slopes of Mt. Elgon constitute a safe domestic water supply source for rural communities. The water points are hand dug and range in depth from 5 to 10 meters. A rope and a bucket technology is the preferred means of getting water from the well. A few boreholes have been developed in institutions like health centers and schools. There are also a few communal and individual boreholes. Thus, sustainable groundwater resources development in the region is influenced by a mix of complex geological factors, climate variability/change and human activities.

The Mt Elgon aquifer as low mineralized water distributed in the catchment area around the slopes of the mountain. However, downslope mineralization is noted to increase as groundwater enters the metamorphic rocks and residence time increases. The study revealed that the concentrations of cations and anions in the groundwater varied spatially and temporally. Abundance of these ions were in the order $\mathrm{Ca}^{2+}>\mathrm{Na}^{+}>\mathrm{Mg}^{2+}>\mathrm{K}^{+}$for most 
samples and $\mathrm{HCO}_{3}{ }^{-}>\mathrm{Cl}^{-}>\mathrm{SO}_{4}{ }^{2-}>\mathrm{NO}_{3}{ }^{-}$. Interpretation of hydrochemical data suggests that calcium carbonate dissolution, ion-exchange processes, silicate weathering are responsible for the groundwater chemistry. The chemical composition also suggests that carbonate dissolution, halite dissolution, $\mathrm{Ca} / \mathrm{Na}$ ion exchange and $\mathrm{Mg} / \mathrm{Na}$ ion exchange are the major processes that control the ground-water chemistry. Chemical results indicate that groundwater is suitable for domestic use but is threatened by anthropogenic and geological factors. Groundwater in the study area is relatively fresh on the mountain slopes and has not been subjected to strong water-rock interaction. In the lowlands, groundwater has gone through significant geochemical evolution.

\subsection{Conclusions}

Groundwater plays a major life support to mankind. It is, in some contexts such as in semi-arid to arid lands, the major source to meet domestic, irrigation and industrial demands. Major ion concentration in groundwater can have negative and positive impacts on human health. Many ions occur naturally in water but sometime high concentration of naturally occurring ions render the water unfit for drinking, irrigation, or other uses. Other ions are chemicals introduced by human activities. Groundwater occurs in a wide range of rock types and is often the cheapest and simplest water supply option. In the study area, groundwater plays a big role in water supply and sustaining large herds of livestock kept by the nomads.

The study recommends regular monitoring of groundwater in the region. Groundwater monitoring is central axis for planning, development and management, but like other parts of Kenya, it is limited both in scope and duration. Besides data that is obtained during the drilling of boreholes, no new data is generally received from borehole operators. Lack of data and information has predicated the need for drilling dedicated observation wells to assess and monitor groundwater resources. The Water Management Authority of Kenya should develop guidelines for the management of aquifers. The codes of practice on groundwater exploration should be adhered to and identified groundwater conservation areas must be protected.

Mt Elgon aquifer is shared by Kenya and Uganda and should therefore managed by the two countries. However, there is no legally binding instrument setting out the terms of engagement between Kenya and Uganda on the sharing of transboundary water (groundwater and surface water). There is need for a Memorandum of Understanding (MOU) setting out terms of engagement in managing transboundary water resources which can later be converted to treaties and agreements setting out the substantive and procedural terms of cooperation.

\section{References}

Abdi, B., \& Osman, D. (2012). Groundwater quality in Wajir (Kenya ) shallow aquifer : An examination of the association between water quality and water-borne diseases in children . La Trobe University. Phd thesis. Retrieved from http://hdl.handle.net/1959.9/504378

Ayalew, M., Chenoweth, J., Malcolm, R., Mulugetta, Y., Okotto, L. G., \& Pedley, S. (2014). Small independent water providers: Their position in the regulatory framework for the supply of water in Kenya and Ethiopia. Journal of Environmental Law, 26(1), 105-128. https://doi.org/10.1093/jel/eqt028

Chelelgo, S., \& Mwaura, A. (2011). Mt Elgon transboundary ecosystem. Western Conservation Area, Kenya. Internal Report, KWS. (Online) Available: https://www.bfn.de/fileadmin/MDB/documents/themen/internationalernaturschutz/2011-AfriBR-14Mwaura Kenya.pdf

Datta, P. S., \& Tyagi, S. K. (1996). Major ion chemistry of groundwater in Delhi area: Chemical weathering processes and groundwater flow regime. Journal of the Geological Society of India, 47(2), 179-188.

Gleeson, T., Alley, W. M., Allen, D. M., Sophocleous, M. A., Zhou, Y., Taniguchi, M., \& Vandersteen, J. (2012). Towards sustainable groundwater use: Setting long-term goals, backcasting, and managing adaptively. Ground Water, 50(1), 19-26. https://doi.org/10.1111/j.1745-6584.2011.00825.x

JICA. 2012. The Project on the Development of the National Water Master Plan (2013) (Progress Report): The Republic of Kenya - Ministry of Water and Irrigation Water Resources Management Authority, (July), 281. (Online) Available http://www.wrma.or.ke/images/presspdf/ProgressReport 4 NWMP 2030.pdf

Luedeling, E., Oord, A. L., Kiteme, B., Ogalleh, S., \& Malesu, M. (2015). Fresh groundwater for Wajir - exante assessment of uncertain benefits for multiple stakeholders in a water supply project in Northern Kenya, 3(March), 1-18. https://doi.org/10.3389/fenvs.2015.00016

MacDonald, A. M., Bonsor, H. C., Calow, R., Taylor, R., \& Lapworth, D. (2011). Groundwater resilience to climate change in Arica. British Geological Survey Open Report, (OR/11/031), 25.

Mailu, G. M. (1997). The impact of urbanization on groundwater quality in Wajir Town, Kenya, (243), $245-253$.

McCall, G. J. H. (1964). Geology of the Sekerr Area. Geological Survey of Kenya. Report No. 65

Miller J.M. 1956. Geology of the Kitale-Cherangani Hills area. Geological Survey of Kenya. Report No. 55

Musau, J., Sang, J., Gathenya, J., \& Luedeling, E. (2015). Hydrological responses to climate change in Mt. Elgon watersheds. Journal of Hydrology: Regional Studies, 3, 233-246. https://doi.org/10.1016/j.ejrh.2014.12.001 
Oiro, S., Comte, J.-C., Soulsby, C., \& Walraevens, K. (2018). Using stable water isotopes to identify spatiotemporal controls on groundwater recharge in two contrasting East African aquifer systems. Hydrological Sciences Journal, 00(00), 1-16. https://doi.org/10.1080/02626667.2018.1459625

Owuor, S. O., \& Foeken, D. W. J. (2009). Water reforms and interventions in urban Kenya. Institutional set-up, emerging impact and challenges, $86 . \quad$ (Online) Available: https://openaccess.leidenuniv.nl/handle/1887/13764

Searle, D.L., (1952). Geology of the area north-west of Kitale. Geological Survey of Kenya. Report No. 19

Taweesin, K., Seeboonruang, U., \& Saraphirom, P. (2018). The Influence of Climate Variability Effects on Groundwater Time Series in the Lower Central. Water. https://doi.org/10.3390/w10030290

UN-Water. (2015). Water for a sustainable world. https://doi.org/10.1016/S1366-7017(02)00004-1

Wang, H., Wang, T., Zhang, B., Li, F., Toure, B., Omosa, I. B., \& Pradhan, M. (2014). Water and

World Health Organization, \& UNICEF. (2017). Progress on Drinking Water, Sanitation and Hygiene. https://doi.org/10.1111/ tmi.12329 